\title{
Comparison of two populations of the pantropical predator Amblyseius largoensis (Acari: Phytoseiidae) for biological control of Raoiella indica (Acari: Tenuipalpidae)
}

\author{
Cleiton A. Domingos • Leandro O. Oliveira • Elisângela G. F. de Morais • \\ Denise Navia • Gilberto J. de Moraes • Manoel G. C. Gondim Jr.
}

Received: 31 May 2012/ Accepted: 29 September 2012

(C) Springer Science+Business Media Dordrecht 2012

\begin{abstract}
The red palm mite, Raoiella indica Hirst (Acari: Tenuipalpidae), was recently introduced in the Americas. It spread quickly throughout coconut palm growing areas, expanding considerably its host range. The invasion of this species has caused high economic impact in several countries. In Brazil, extensive areas are expected to be affected. For logistical reasons and other concerns, chemical control does not seem desirable for the control of this pest in most Latin American countries. Biological control of $R$. indica by introducing exotic natural enemies seems to be an important control measure to be considered. Surveys in many countries have shown that Amblyseius largoensis (Muma) (Acari: Phytoseiidae) is a very common predator on coconut palms. This study compared the biology of a population of $A$. largoensis found for a long time in association with $R$. indica in La Reunion Island (Indian Ocean) with a population from Roraima State (northern Brazil), where $R$. indica was first found about two and a half years ago. No significant differences were observed between populations in relation to the duration of different immature stages or total survivorship. However, the oviposition period, prey consumption and net reproductive rate were significantly higher for the La Reunion population,
\end{abstract}

C. A. Domingos · M. G. C. Gondim Jr. ( $\bowtie)$

Depto. Agronomia, Área de Fitossanidade, Universidade Federal Rural de Pernambuco, Recife,

PE 52171-900, Brazil

e-mail: mguedes@depa.ufrpe.br

L. O. Oliveira · E. G. F. de Morais

Laboratório de Entomologia, Embrapa Roraima, BR 174, Km 8, Distrito Industrial, Caixa Postal 133, Boa Vista, RR 69301-970, Brazil

e-mail: elisangela@cpafrr.embrapa.br

D. Navia

Laboratório de Quarentena Vegetal, Embrapa Recursos Genéticos e Biotecnologia,

Parque Estação Biológica, final w5 Norte, Caixa Postal 02372, Brasília, DF CEP 70.770-900, Brazil

e-mail: navia@cenargen.embrapa.br

G. J. de Moraes

Depto. Entomologia e Acarologia, Escola Superior de Agricultura "Luiz de Queiroz",

Universidade de São Paulo, Piracicaba, SP 13418-900, Brazil

e-mail: gjmoraes@esalq.usp.br 
warranting further investigation to determine whether that population should be released in Roraima to control the pest.

Keywords Coconut palm $\cdot$ Red palm mite $\cdot$ Phytoseiid $\cdot$ Biological control $\cdot$ Arecaceae Quarantine pest

\section{Introduction}

The genus Raoiella Hirst (Acari: Tenuipalpidae) consists of twelve valid described species known until recently from the Palaearctic, Afrotropical, Oriental and Australian regions (Mesa et al. 2009), in addition to nine possible new species recently discovered in Australia (Dowling et al. 2012). The red palm mite, Raoiella indica Hirst, was first found in the New World about 7 years ago (Flechtmann and Etienne 2004), but it is now found in different countries of this region, including northern South America (Navia et al. 2011). After an extensive study conducted by Dowling et al. (2012), it was suggested that the center of origin of this genus is either Africa or the Middle East. However, Dowling et al. (2008) concluded that the Caribbean population of $R$. indica likely came from Réunion Island. Date and coconut palms are the most common hosts of this mite species in most places where it is found in the Old World as well as Areca catechu (Linn). However, for unknown reasons, it expanded tremendously its host range when it reached the New World, which includes mainly Arecaceae but also other monocotyledons (Navia et al. 2011; Carrillo et al. 2012a). Data concerning the economic impact related to the incidence of this mite on difference hosts have not been published, but it has been considered to be very high in some Latin American countries.

This mite was found in Brazil in July 2009 (Navia et al. 2011) in Roraima State, near the Venezuelan border. The coconut palm is not commercially important in this state, but it is extensively cultivated along the Brazilian coast and in irrigated areas of the Brazilian northeast (Cuenca et al. 2002). Brazil is the fourth largest world coconut producer (FAOSTAT 2011), with $70 \%$ of the cultivation area being dedicated to giant varieties for copra production (Aragão 2002). However, in most of this country coconut plantations are not well managed (Holanda et al. 2009) and basically nothing is done by coconut growers in terms of pest control (Ferreira 2009). For this reason, yield is low in most of the country, corresponding to approximately 34 fruits/plant/year (Wanderley and Lopes 2009), and it could be reduced further when affected by the red palm mite. In addition to coconut, several native Arecacea species that are potential hosts for the mite are exploited by lowincome populations in northern and northeastern Brazil (Lorenzi et al. 2010). These may also be severely affected by this pest.

Most of the common coconut palms cultivated in different parts of the world are very often over $10 \mathrm{~m}$ tall, making it very difficult for growers to eventually control $R$. indica with chemicals. This major difficulty, the fact that most coconut growers are not experienced in using chemicals for the control of pest organisms and the growing concern about the environmental impact of those products have led to the consideration of alternative methods to control $R$. indica. In this regard, the search for effective natural enemies in areas where the pest is known to be present but where it is suspected to be less harmful has been conducted. In an exploration conducted on La Reunion Island, in the Indian Ocean, Moraes et al. (2012) determined that the phytoseiid Amblyseius largoensis (Muma) was the predominant predator associated with the pest. As explained in that paper, a survey was conducted in La Réunion given that the pest was known to occur in that island at a level 
that did not cause major damage to the coconut plants. This same species has also been found in many other countries in association with the red palm mite (Carrillo et al. 2012c), including Roraima State (our unpublished data). A. largoensis is also predominant on palms and other plant species in the New World (Moore and Howard 1996; Gondim and Moraes 2001; Moraes et al. 2004; Lawson-Balagbo et al. 2008). A colony of this species was collected in La Reunion in early 2011 and introduced to Brazil. The objective of this work was to compare the development, reproduction and predation of the La Reunion and Roraima populations under laboratory conditions, to decide whether it would be worthwhile to consider the eventual field release of the introduced strain.

\section{Materials and methods}

This work was conducted in the entomology laboratory of Embrapa Roraima, in Boa Vista, State of Roraima, Brazil, at $27{ }^{\circ} \mathrm{C}, 60 \pm 10 \% \mathrm{RH}$ and 12:12 h light:dark photophase.

Collection and rearing of predators

One of the populations of A. largoensis used in the study corresponded to a colony initiated with approximately 100 mites collected from coconut palms from different areas of La Reunion Island in February 2011, with permission of the French authorities (Moraes et al. 2012), and introduced to Brazil with permission of the Brazilian Ministério da Agricultura e Reforma Agrária (Import Permit 296/2010). The colony was established on a banana leaf disc (14 $\mathrm{cm}$ in diameter) placed abaxial side up on a 1-cm thick polyethylene foam disc of the same diameter. Each disc was placed in a Petri dish $(16 \mathrm{~cm}$ in diameter) and its margin was covered with hydrophilic cotton that was continuously soaked by daily addition of distilled water to the dish, to maintain the turgidity of the disc and to prevent the mites from escaping. The colony was fed with a mixture of all stages of $R$. indica locally obtained from coconut palms.

The other population of A. largoensis corresponded to a colony initiated with mites collected in April of 2011 from coconut palms grown at Embrapa Roraima $\left(57^{\circ} 034^{\prime} \mathrm{N}\right.$; $\left.60^{\circ} 42^{\prime} 19.7^{\prime \prime} \mathrm{W}\right)$. The colony was maintained as described above for the introduced strain. Care was taken to avoid mutual infestations of the colonies.

\section{Experimental procedure}

Each experimental unit consisted of a square of banana leaf $(3 \times 3 \mathrm{~cm})$ placed, abaxial side up, on a filter paper disc (14 $\mathrm{cm}$ in diameter) placed onto a $1-\mathrm{cm}$ thick polyethylene foam disc of same diameter in a Petri dish $(16 \mathrm{~cm}$ in diameter). The edges of each unit were covered with a layer of hydrophilic cotton to prevent dehydration. A thin line of nonsoluble entomological glue was placed on top of the cotton layer to prevent mites from escaping. Each Petri dish contained nine units and two dishes were used in each of the five replicates of the experiment.

After setting up the units, 30 red palm mite nymphs (protonymphs and deutonymphs) obtained from naturally infested coconut palms were transferred to each experimental unit with a brush. Subsequently, a female of the introduced A. largoensis population was transferred to each of the units of half of the Petri dishes, while a female of Roraima population was transferred to each of the remaining units. After $12 \mathrm{~h}$, the predator females and the eggs were removed, except for a single egg per unit. The predators originating from 
these eggs were reared to adulthood, examining each of them every $12 \mathrm{~h}$ to determine the duration and survivorship of each developmental stage as well as the number of prey consumed.

Immediately after a female predator reached adulthood, a male was taken from the respective colony and put together with the female. Dead males were replaced by new males from the same respective colonies. Oviposition, female longevity and prey consumption for each unit (female + male) were monitored once a day. Eggs laid in the first 10 days of the oviposition period were isolated to determine the sex ratio.

All developmental stages were fed continuously with nymphs (protonymphs and deutonymphs) of the red palm mites. Prey consumed in each unit was replaced once a day to a total of 30 nymphs per unit. Care was taken to prevent mortality of the mites while handling; thus, when transferring to a unit, each nymph was gently touched with the tip of a fine brush and then gently collected with the brush as soon as it started to move.

Data analysis

Average durations of immature stages, survivorship, longevity of adult female, oviposition rates and prey consumption of both populations were compared by $t$ tests using the method of pooled data $(p=0.05)$, using SAS (2001). Fertility life table parameters ( $T$ mean generation time, $r_{\mathrm{m}}$ intrinsic rate of population increase, $R_{0}$ net reproductive rate, $\lambda$ finite rate of population increase and $D T$ average time in days for doubling of the population in number) and associated confidence intervals were calculated using the Jackknife method, which allows pair wise comparisons using Student's $t$ tests (Maia et al. 2000).

\section{Results}

No significant differences were observed between populations in terms of the duration of each immature stage of the predator. However, the duration of the total immature period (egg to adult) of the Roraima population was slightly, but significantly, shorter $\left(t_{8}=\right.$ $-3.56 ; p=0.0074$ ) than that of the La Reunion population (Table 1). No statistically significant differences in terms of survivorship of each immature stage or of the total immature period, or in terms of prey consumption by the larvae were observed. However, protonymphs, deutonymphs and the total immature period of specimens from La Reunion had significantly higher prey consumption $\left(t_{8}=-4.68 ; p=0.0016\right)$.

The La Reunion population had better performance in relation to various other biological parameters (Table 2), as evidenced by its significantly shorter periods of preoviposition $\left(t_{8}=7.71 ; p<0.0001\right)$ and post-oviposition $\left(t_{8}=3.17 ; p=0.013\right)$, longer periods of oviposition $\left(t_{8}=-2.89 ; p=0.020\right)$ and higher daily oviposition $\left(t_{8}=-3.22\right.$; $p=0.012)$, fecundity $\left(t_{8}=-3.26 ; p=0.012\right)$, daily prey consumption $\left(t_{8}=-4.46\right.$; $p=0.0021)$, total prey consumption $\left(t_{8}=-4.90 ; p=0.0012\right)$ and net reproductive rate (non-overlapping $95 \%$ confidence interval). However statistically significant differences were not observed for several other parameters, namely female longevity, sex ratio, mean generation time, intrinsic rate of population increase, finite rate of population increase and doubling time of the population.

The slightly higher average daily oviposition rate determined for the La Reunion population (Table 2) was attained by the maintenance of higher daily rates of egg laying during most of the oviposition period (Fig. 1). The maximum levels of daily oviposition of 


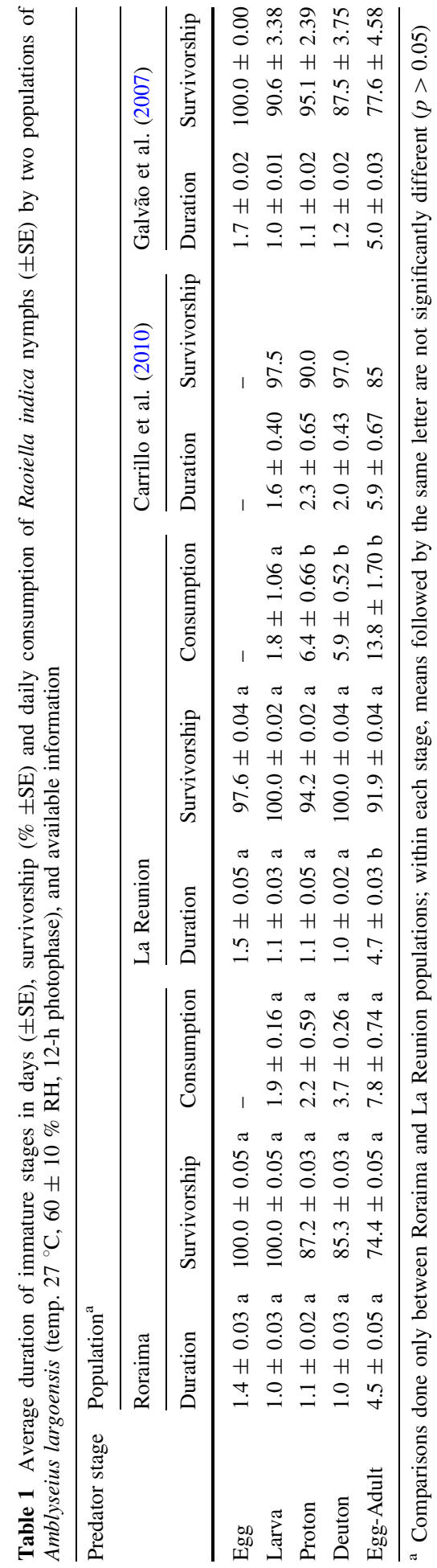


Table 2 Biological parameters (mean \pm SE or mean followed by $95 \%$ confidence intervals for life table parameters) of two populations of Amblyseius largoensis fed with nymphs of Raoiella indica (temp. $27^{\circ} \mathrm{C}$, $60 \pm 1 \%$ R.H., 12-h photophase), and available literature information

\begin{tabular}{|c|c|c|c|c|}
\hline \multirow[t]{2}{*}{ Biological parameters } & \multicolumn{4}{|l|}{ Population $^{\mathrm{a}}$} \\
\hline & Roraima & La Reunion & $\begin{array}{l}\text { Carrillo et al. } \\
(2010)\end{array}$ & $\begin{array}{l}\text { Galvão et al. } \\
\text { (2007) }\end{array}$ \\
\hline Pre-oviposition (days) & $3.2 \pm 0.16 \mathrm{a}$ & $1.9 \pm 0.06 \mathrm{~b}$ & $3.2 \pm 1.74$ & $0.9 \pm 0.01$ \\
\hline Oviposition (days) & $20.5 \pm 0.86 b$ & $25.3 \pm 1.40 \mathrm{a}$ & $14.1 \pm 8.30$ & $20.4 \pm 0.58$ \\
\hline Post-oviposition (days) & $2.6 \pm 0.05 \mathrm{a}$ & $2.1 \pm 0.18 \mathrm{~b}$ & - & $5.3 \pm 0.63$ \\
\hline Female longevity (days) & $26.4 \pm 0.71 \mathrm{a}$ & $29.8 \pm 1.57 \mathrm{a}$ & $23.7 \pm 13.4$ & $26.6 \pm 0.84$ \\
\hline $\begin{array}{l}\text { Daily oviposition rate/ } \\
\text { female }\end{array}$ & $1.4 \pm 0.05 \mathrm{~b}$ & $1.7 \pm 0.07 \mathrm{a}$ & $1.63 \pm 0.27$ & $1.7 \pm 0.04$ \\
\hline Fecundity/female & $36.9 \pm 1.15 \mathrm{~b}$ & $49.7 \pm 3.73 \mathrm{a}$ & $19.96 \pm 14.6$ & $33.2 \pm 1.07$ \\
\hline $\begin{array}{l}\text { Daily prey consumption/ } \\
\text { female }\end{array}$ & $6.2 \pm 0.28 \mathrm{~b}$ & $9.5 \pm 0.51 \mathrm{a}$ & - & - \\
\hline $\begin{array}{l}\text { Total prey consumption/ } \\
\text { female }\end{array}$ & $161.9 \pm 7.98 b$ & $259.8 \pm 18.31 \mathrm{a}$ & - & - \\
\hline Sex ratio & $0.75 \pm 0.01 \mathrm{a}$ & $0.61 \pm 0.01 \mathrm{a}$ & $0.73 \pm 0.19$ & $0.71 \pm 0.01$ \\
\hline${ }^{4} T$ & $\begin{array}{l}15.77 \\
(14.82-16.72) \mathrm{a}\end{array}$ & $\begin{array}{l}16.63 \\
(15.70-17.56) \mathrm{a}\end{array}$ & $19.95 \pm 1.55$ & $\begin{array}{l}12.21 \\
\quad(11.81-12.61)\end{array}$ \\
\hline${ }^{4} r_{\mathrm{m}}$ & $0.19(0.19-0.20)$ a & $0.20(0.19-0.21) \mathrm{a}$ & $0.13 \pm 0.008$ & $0.24(0.23-0.24)$ \\
\hline${ }^{4} R_{0}$ & $\begin{array}{l}21.83 \\
(19.53-24.14) b\end{array}$ & $\begin{array}{l}28.14 \\
(25.14-31.15) \mathrm{a}\end{array}$ & $12.59 \pm 1.46$ & $\begin{array}{l}19.42 \\
(18.33-20.50)\end{array}$ \\
\hline${ }^{4} \lambda$ & $1.22(1.21-1.23) \mathrm{a}$ & $1.22(1.21-1.23) \mathrm{a}$ & - & $1.27(1.26-1.28)$ \\
\hline${ }^{4} D T$ (days) & $3.54(3.39-3.70) \mathrm{a}$ & $3.45(3.31-3.59) \mathrm{a}$ & - & $2.85(2.77-2.93)$ \\
\hline
\end{tabular}

${ }^{a}$ Comparisons done only between Roraima and La Reunion populations; means followed by the same letter in a line are not statistically different $(P>0.05)$; first eight parameters compared by $t$ tests; last five parameters compared by the method of Maia et al. (2000). $T$ mean generation time, $r_{\mathrm{m}}$ intrinsic rate of population increase, $R_{0}$ net reproductive rate, $\lambda$ finite rate of population increase, $D T$ average time in days for doubling of the population in number

both populations occurred between the 10th and 12th days after the onset of oviposition. Thereafter, asymptotic declines of oviposition levels were observed.

Similarly to what was determined for oviposition, the higher average daily rate of prey consumption of the La Reunion population (Table 2) was attained by the maintenance of higher rates of daily prey consumption thorough the adult stage (Fig. 2). In this population, the highest levels of consumption occurred between the 10th and 15th days, with a slight reduction thereafter. Prey consumption rate of the Roraima population reached maximum levels between the 20th and 25th days, reducing also thereafter.

\section{Discussion}

The developmental periods of both populations were comparable (Table 1) to those determined by Galvão et al. (2007) for a population of the same predator collected near Recife, PE, Brazil, and offered other food sources (Tetranychus urticae Koch or pollen of Ricinus communis L. plus honey). However, both populations considered in this study had shorter developmental periods than determined by Carrillo et al. (2010) for a Florida 
Fig. 1 Daily oviposition (mean $\pm \mathrm{SE}$ ) of females of two populations of Amblyseius indica nymphs (temp. $27^{\circ} \mathrm{C}$, $60 \pm 1 \%$ RH, 12-h photophase) largoensis fed with Raoiella

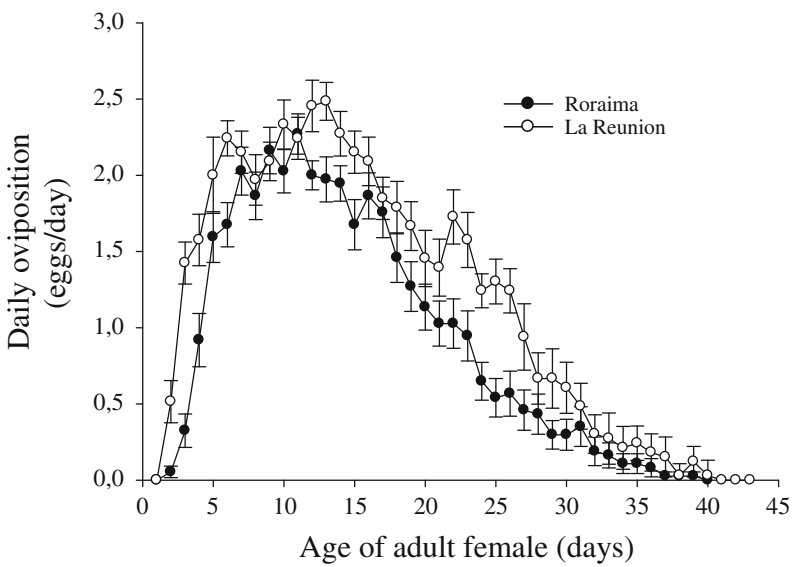

Fig. 2 Daily consumption (average $\pm \mathrm{SE}$ ) of nymphs of Raoiella indica by females of two populations of Amblyseius largoensis during the immature and adult stages (temp. $27^{\circ} \mathrm{C}$, $60 \pm 1 \% \mathrm{RH}, 12-\mathrm{h}$ photophase)

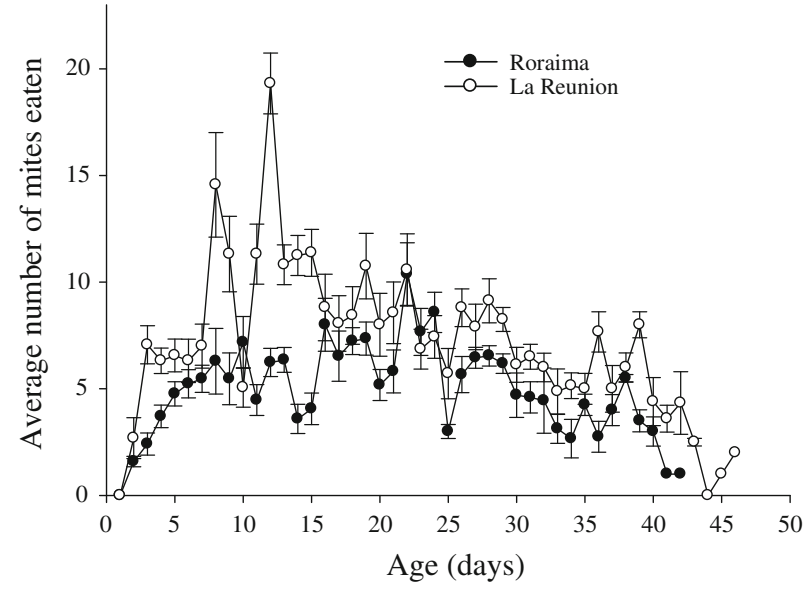

population maintained at similar temperature and humidity conditions as used in this experiment, but fed all developmental stages. Total survivorship of both populations of this study was approximately the same as the populations studied by Galvão et al. (2007) and Carrillo et al. (2010).

Particularly interesting was the long oviposition period of the La Reunion population. It not only was determined to be longer than the Roraima population, but it was almost twice as long as the Florida population studied by Carrillo et al. (2010). As the average daily oviposition rates for the La Reunion and the Florida population were about the same, the total number of eggs laid was considerably higher for the former. Consequently, intrinsic rate of population increase and net reproductive rate were also higher.

Moutia (1958) reported Amblyseius caudatus Berlese as predator of red palm mite in coconut palm trees on the Mauritius Island, observing that adults of that predator could consume on average upto 10.6 eggs/day and a total of 490 eggs throughout their lifespan. In this work, immature and adult females of the La Reunion population consumed totals of about 14 and 260 red palm mite nymphs, respectively. Eggs of $R$. indica $(90-100 \mu \mathrm{m}$ in length) are much smaller than protonymphs $(180-200 \mu \mathrm{m})$ and deutonymphs (240-250 $\mu \mathrm{m})$ (Nageshachandra and Channabasavanna 1984; Kane et al. 2012). Therefore, 
when comparing the dimensions of these stages, the performance of A. largoensis can be considered close to or even higher than that obtained by Moutia (1958) for A. caudatus. It is possible that the species reported by Moutia (1958) as A. caudatus is the same as $A$. largoensis; Mauritius is an island relatively close to La Reunion, where A. largoensis was determined to be the dominant phytoseiid on coconuts in association with the palm red mite. A. caudatus was described from Indonesia, where A. largoensis has also been reported. However, the description of A. caudatus was not adequately done for what is known today to characterize a phytoseiid species. From information available in the literature, both nominal species are morphologically very similar, suggesting that they could represent the same species (Carrillo et al. 2012c). Several detailed studies on the relation between the red palm mite and A. largoensis has been recently published (Carrillo et al. 2010; 2012a, b, c Carrillo and Peña 2012). In one of those studies (Carrillo and Peña 2012) the authors observed a preference of A. largoensis to feed on eggs than on other stages of the red palm mite. In another study, Carrillo et al. (2012b) observed that previous exposure of $A$. largoensis to the red palm mite turned those predators more likely to consume the latter, stating that plasticity of response of A. largoensis to the red palm mite could be associated with selection, learning or a combination of these two processes. These interpretations could explain the better performance of the La Reunion population, which has been exposed to the red palm mite as a prey for much longer than the Roraima population. If that were the case, probably within some time a new comparison of the Roraima and the La Reunion populations could result in no significant differences between them. The red palm mite was first found in July 2009 in the region where we collected (in April of 2011) the specimens used to start the predator colony used in this study. However, the La Reunion population might still have biological characteristics not found in the Roraima population, and thus not prone to be selected for in that population. These characteristics could still conceivably make the La Reunion population more effective than the Roraima population after the exposure of the latter to the red palm mite for many years.

Amblyseius largoensis is one of the most frequent and abundant predators on coconut leaves (Moore and Howard 1996; Gondim and Moraes 2001; Moraes et al. 2004; LawsonBalagbo et al. 2008; Carrillo et al. 2012c). This species is known from several tropical countries around the world on a great diversity of plant species (Moraes et al. 2004). Similarly to other species of the genus (McMurtry and Croft 1997), A. largoensis is a generalist predator that feeds on a diversity of mites, small insects and other food types, including pollen (Kamburov 1971; Yue and Tsai 1996; Rodriguez and Ramos 2004; Galvão et al. 2007; 2008). Sucking insects and other phytophagous mites are often found on coconut leaflets (Howard et al. 2001; Navia et al. 2007); several of these, could also serve as prey for this predator, mainly mites of the families Eriophyidae, Tenuipalpidae and Tetranychidae. Results of the present study showed that the performance of this predator on the red palm mites was comparable to that determined by Galvão et al. (2007) with other food sources. Thus, the red palm mite could be considered an appropriate diet for the development and reproduction of A. largoensis. Carrillo et al. (2012b) demonstrated that this predator can consume high numbers of eggs of the red palm mite regardless of its previous feeding experience, while Carrillo et al. (2012c) reported that in Trinidad Tobago and Puerto Rico, the population level of A. largoensis on coconut increased after the arrival of the red palm mite.

From a biological standpoint, the La Reunion population could be considered less efficient than the population of Roraima, given that individuals of La Reunion population needed to consume more prey to have a biological performance similar to the population of Roraima in terms of development and reproduction. This result suggests a higher energy 
demand of the La Reunion population for its maintenance. In principle, this result may indicate lower adaptation of this population to consume the red palm mite. However, this conclusion does not seem logical, because the La Reunion population has most certainly lived in association with the prey for much longer than the Roraima population. On the other hand, from a practical standpoint, the La Reunion population seems to be more efficient in controlling the red palm mite, because a larger number of mites are preyed. These results seem sufficient to justify complementary studies under controlled conditions and in semi-field tests, to evaluate the performance of the La Reunion population under the climatic conditions of Roraima. On the other hand, interpretation of the field results can be complicated by the fact that A. largoensis is already present in Roraima and that distinguishing members of the two populations in the field may be difficult. However, although morphologically very similar, members of these populations could have minor morphological differences to allow their separation, as recently shown for phytoseiid populations from coconut in Africa and South America (Sourassou et al. 2011, 2012). Before field releases are further considered, it would seem advisable to determine the reproductive compatibility of mites of those populations, as well as to investigate the possibility to separate them with molecular tools, as demonstrated for several phytoseiid species or populations, as reported by Bowman and Hoy (2012); Sourassou et al. (2012). Bowman \& Hoy (2012) worked on two populations of A. largoensis, from Mauritius and Florida (USA), separating them with the use of molecular tools. In any case, a complication in determining the fate of the eventual release in Roraima might rise, in case the two populations interbreed under natural conditions.

Therefore, morphometric, interbreeding and molecular comparisons between these two populations are warranted, to allow the evaluation of results of possible field releases of the La Reunion population in Roraima.

Acknowledgments We thank the Centre de Coopération Internationale em Recherche Agronomique pour Le Développement (CIRAD) for the logistical support in obtaining the population from La Reunion. We also thank the National Council for Scientific and Technological Development (CNPq), the Coordination of Personnel Improvement for Higher Education (CAPES), the Brazilian Agricultural Research Corporation (Embrapa-Roraima) and the Foundation for Science and Technology of the State of Pernambuco (FACEPE) for logistical and financial support. Finally, we are grateful to Serge Kreiter and Tatiane Marie Martins Gomes de Castro for their assistance in the collection.

\section{References}

Aragão WM (2002) Introdução. In: Aragão WM (ed) Coco Pós-colheita. Embrapa Tabuleiros Costeiros, Aracaju, pp 9-10

Bowman HM, Hoy MA (2012) Molecular discrimination of phytoseiids associated with the red palm mite Raoiella indica (Acari: Tenuipalpidae) from Mauritius and south Florida. Exp Appl Acarol 57:395-407

Carrillo D, Peña JE (2012) Prey-stage preferences and functional and numerical responses of Amblyseius largoensis (Acari: Phytoseiidae) to Raoiella indica (Acari: Tenuipalpidae). Exp Appl Acarol 57:361-372

Carrillo D, Peña JE, Hoy MA, Howard FJ (2010) Development and reproduction of Amblyseius largoensis (Acari: Phytoseiidae) feeding on pollen, Raoiella indica (Acari: Tenuipalpidae), and other microarthropods inhabiting coconuts in Florida, USA. Exp Appl Acarol 52:119-129

Carrillo D, Amalin D, Hosein F, Roda A, Duncan RE, Peña JE (2012a) Host plant range of Raoiella indica (Acari: Tenuipalpidae) in areas of invasion of the New World. Exp Appl Acarol 57:271-289

Carrillo D, Coss ME, Hoy MA, Peña JE (2012b) Variability in response of four populations of Amblyseius largoensis (Acari: Phytoseiidae) to Raoiella indica (Acari: Tenuipalpidae) and Tetranychus gloveri (Acari: Tetranychidae) eggs and larvae. Biol Control 60:39-45 
Carrillo D, Howard Frank J, Rodrigues JCV, Peña JE (2012c) A review of the natural enemies of the red palm mite, Raoiella indica (Acari: Tenuipalpidae). Exp Appl Acarol 57:347-360

Cuenca MAG, Resende JM, Saggin OJ Jr, Reis CS (2002) Mercado brasileiro do coco: situação atual e perspectivas. In: Aragão WM (ed) Coco Pós-colheita. Embrapa Tabuleiros Costeiros, Aracaju, pp 11-18

Dowling APG, Ochoa R, Beard JJ (2008) Preliminary results on phylogeographic patterns of the invasive red palm mite, Raoiella indica (Prostigmata: Tenuipalpidae). In: Proceedings of the 6th European congress of acarology, pp 147-154

Dowling APG, Ochoa R, Beard JJ, Welbourn WC, Ueckermann EA (2012) Phylogenetic investigation of the genus Raoiella (Prostigmata: Tenuipalpidae): diversity, distribution, and world invasions. Exp Appl Acarol 57:257-269

FAOSTAT (2011) World Production. http://faostat.fao.org. Accessed 19 Mar 2012

Ferreira JMS (2009) Pragas e métodos de controle ajustados à baixa capacidade de investimento dos pequenos produtores rurais. In: Cintra FLD, Fontes HR, Passos EEM, Ferreira JMS (eds) Fundamentos tecnológicos para a revitalização das áreas cultivadas com coqueiro gigante no Nordeste do Brasil. Embrapa Tabuleiros Costeiros, Aracaju, pp 191-218

Flechtmann CHW, Etienne J (2004) The red palm mite Raoiella indica Hirst, a threat to palms in the Americas (Acari: Prostigmata: Tenuipalpidae). Syst Appl Acarol 9:109-110

Galvão AS, Gondim MGC Jr, Moraes GJ, Oliveira JV (2007) Biology of Amblyseius largoensis (Muma) (Acari: Phytoseiidae), a potential predator of Aceria guerreronis Keifer (Acari: Eriophyidae) on coconut palms. Neotrop Entomol 36:465-470

Galvão AS, Gondim MGC Jr, Moraes GJ, Oliveira JV (2008) Exigências térmicas e tabela de vida de fertilidade de Amblyseius largoensis. Cienc Rural 38:1817-1823

Gondim MGC Jr, Moraes GJ (2001) Phytoseiid mites (Acari: Phytoseiidae) associated with palm trees (Arecaceae) in Brazil. Syst Appl Acarol 6:65-94

Holanda JS, Alves MCS, Medeiros AA (2009) Adubação de coqueiro gigante tendo como foco a pequena produção e a baixa capacidade de investimento. In: Cintra FLD, Fontes HR, Passos EEM, Ferreira JMS (eds) Fundamentos tecnológicos para a revitalização das áreas cultivadas com coqueiro gigante no Nordeste do Brasil. Embrapa Tabuleiros Costeiros, Aracaju, pp 91-106

Howard FW, Moore D, Giblin-Davis RM, Abad RG (2001) Insects on palms. CABI, Wallingford, p 400

Kamburov SS (1971) Feeding, development, and reproduction of Amblyseius largoensis on various food substances. J Econ Entomol 64:643-648

Kane EC, Ochoa R, Mathurin G, Erbe EF, Beard JJ (2012) Raoiella indica (Acari: Tenuipalpidae): an exploding mite pest in the neotropics. Exp Appl Acarol 57:215-225

Lawson-Balagbo LM, Gondim MGC Jr, Moraes GJ, Hanna R, Schausberger P (2008) Exploration of the acarine fauna on coconut palm in Brazil with emphasis on Aceria guerreronis (Acari: Eriophyidae) and its natural enemies. Bull Entomol Res 98:83-96

Lorenzi H, Noblick LR, Kahn F, Ferreira E (2010) Flora brasileira Lorenzi: Arecaceae (palmeiras). Nova Odessa, Instituto Plantarum, p 384

Maia AHN, Luiz AJB, Campanhola C (2000) Statistical inference on associated fertility life table parameters using Jackknife technique: computational aspects. J Econ Entomol 93:511-518

McMurtry JA, Croft BA (1997) Life-styles of phytoseiid mites and their role in biological control. Ann Rev Entomol 42:291-321

Mesa NC, Ochoa R, Welbourn WC, Evans GA (2009) A catalog of the Tenuipalpidae (Acari) of the World with a key to genera. Zootaxa 2098:1-185

Moore D, Howard FW (1996) Coconuts. In: Lindquist EE, Sabelis MW, Bruin J (eds) Eriophyoid mites: their biology, natural enemies and control. Elsevier, Amsterdam, pp 561-570

Moraes GJ, McMurtry JA, Denmark HA, Campos CB (2004) A revised catalog of the mite family Phytoseiidae. Zootaxa 434:1-494

Moraes GJ, Castro TMMG, Kreiter S, Quilici S, Gondim MGC Jr, Sá LAN (2012) Search for natural enemies of Raoiella indica Hirst in La Réunion Island (Indian Ocean). Acarologia 52:129-134

Moutia LA (1958) Contribution to study of some phytophagous acarina and their predators in Mauritius. Bull Entomol Res 49:59-75

Nageshachandra BK, Channabasavanna GP (1984) Plant mites. In: Griffths DA, Bowman CE (eds) Acarology VI. Ellis Horwood, West Sussex, pp 785-790

Navia D, Gondim MGC Jr, Moraes GJ (2007) Eriophyoid mites (Acari: Eriophyoidea) associated with palm trees. Zootaxa 1389:1-30

Navia D, Marsaro AL Jr, Silva FR, Gondim MGC Jr, Moraes GJ (2011) First report of the red palm mite, Raoiella indica Hirst (Acari: Tenuipalpidae), in Brazil. Neotrop Entomol 40:409-411 
Rodriguez H, Ramos M (2004) Biology and feeding behavior of Amblyseius largoensis (Muma) (Acari: Phytoseiidae) on Polyphagotarsonemus latus (Banks) (Acari: Tarsonemidae). Rev Protec Vegetal 19:73-79

SAS Institute (2001) SAS/STAT user's guide, version 8.02, TS level 2MO. SAS Institute, Cary, NC

Sourassou NF, Hanna R, Zannou I, Moraes GJ, Negloh K, Sabelis MW (2011) Morphological variation and reproductive incompatibility of three coconut-mite-associated populations of predatory mites identified as Neoseiulus paspalivorus (Acari: Phytoseiidae). Exp Appl Acarol 53:323-338

Sourassou NF, Hanna R, Zannou I, Breeuwer JAJ, Moraes GJ, Sabelis MW (2012) Morphological, molecular and cross-breeding analysis of geographic populations of coconut-mite associated predatory mites identified as Neoseiulus baraki: evidence for cryptic species? Exp Appl Acarol 57:15-36

Wanderley M, Lopes GMB (2009) Importância sócio-econômica da produção de coco seco no Brasil. In: Cintra FLD, Fontes HR, Passos EEM, Ferreira JMS (eds) Fundamentos tecnológicos para a revitalização das áreas cultivadas com coqueiro gigante no Nordeste do Brasil. Embrapa Tabuleiros Costeiros, Aracaju, pp 13-23

Yue BS, Tsai JH (1996) Development, survivorship, and reproduction of Amblyseius largoensis (Acari: Phytoseiidae) on selected plant pollens and temperatures. Environ Entomol 25:488-494 